\title{
Zakat Impact on Poverty and Welfare of Mustahik: A CIBEST Model Approach ${ }^{1}$ Irfan Syauqi Beik ${ }^{1 *}$ and Caesar Pratama ${ }^{2}$ \\ ${ }^{1,2}$ Bogor Agricultural University, Bogor, Indonesia
}

\begin{abstract}
This research aims to analyze the impact of productive zakat program in poverty alleviation of mustahik households, based on materially and spiritually aspects. Primary data was used as the source of data through distributing administered questionnaires in four rural areas in Bogor Regency. 121 respondents had been interviewed. They were the recipients of Masyarakat Mandiri program of Dompet Dhuafa Amil Institution. CIBEST model which have been developed by Beik dan Arsyianti (2014) was used as the tool of analysis. CIBEST model comprising four indices is used as tool of analysis. These indices are welfare index, material poverty index, spiritual poverty index and absolute poverty index. It is found that the presence of zakat utilization program is able to increase welfare index of the mustahik by 147.14 percent. The material poverty index, spiritual poverty index and absolute poverty index can also be reduced by 49.6 percent 1.6 and 12.3 percent, respectively. Meanwhile, welfare index increase by 63.7 percent. In conclusion, productive zakat program give positive impact to the mustahik household life.
\end{abstract}

Keywords: CIBEST model, Islamic poverty index, poverty, productive-based zakat program

\section{INTRODUCTION \\ Background}

Poverty is still a multidimensional problem in this world, especially for developing country like Indonesia. Regulations and strategies have been established in order to reduce the poverty rate. However, the target of United Nation as mentioned in 2000 Summit, failed to be achieved in 2015. Economy crisis was blamed as one of the cause, including 2008 crisis. The effect has reached the growth of economy which was decreasing, and a trade-off between the growth and the distribution of economy (Beik, 2013).

* Corresponding author. Email address: irfan_beik@ipb.ac.id; qibeiktop@gmail.com

${ }^{1}$ Earlier version of this paper has been presented in the 3rd Islamic Economics and Finance Forum (Forum Riset Ekonomi dan Keuangan Syariah III) organized by Otoritas Jasa Keuangan (OJK), DPP Ikatan Ahli Ekonomi Islam (IAEI) and Faculty of Economics and Business, University of Indonesia, April 28-29, 2015. 


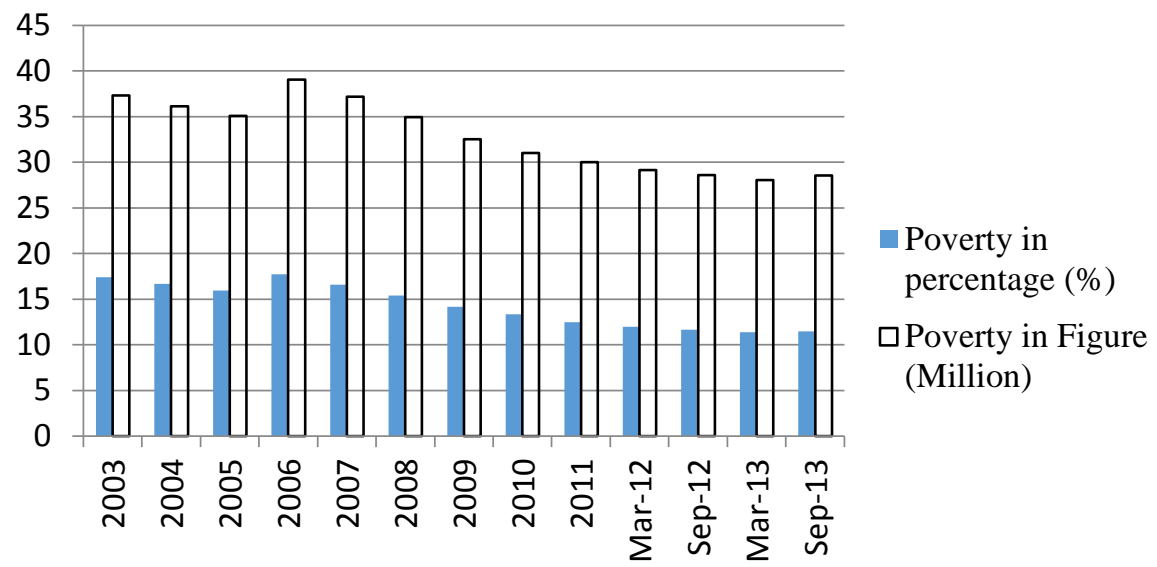

Figure 1 The amount and percentage of poverty in Indonesia, 2003-2013

Source : Statistic Indonesia (2015)

We can say, from Figure 1, that poverty in Indonesia is decreasing, except in 2005-2006, there was a slight increasing in poverty from 35.10 million people to 39.05 million. A minor increasing also happened in March 2013 to September 2013 when the poverty increased from 28.07 million people to 28.55 million.

According to the Millennium Development Goals (MDGs) which targeted poverty reduction up to 7.5 percent from the total population, even though the figure is decreasing, the global target still far away to be achieved. This is due to the poverty rate in Indonesia that is still around 11 percent of the total population.

Therefore, a new approach for reducing poverty is needed. Ishaq (2002) stated that one of the reason why the problem is still occurred until now is because countries and poverty alleviation-related organizations are neglecting the spiritual values, believe, and local culture. Economic regulations, so far, are established based on conventional economic framework which ignores spiritual values (Beik 2013). In Islam, to this extent, zakat has a crucial role in the economy.

Rasulullah stated that Allah has obliged the rich Muslim to pay zakat, so no one will suffer from hunger and lack of clothing unless the rich among us are bakhil (parsimonious) (narrated by Imam Thabrani). The hadith indicates that zakat has strategic role as well as the optimum instrument to reduce poverty and income gap. Indonesia, as the biggest Muslim populated country in the world, should integrate zakat, infak, wakaf in its country's development program.

Actually, Indonesia already has a regulation in managing zakat funds. Based on the Act Number 23 year 2011 about Zakat Management, the National Board of Zakat (BAZNAS) takes the responsibility and authority to coordinate all BAZNAS in every province, city/regency, as well as all formal Amil Institutions (LAZ) launched by society in all over Indonesia. These Amil Institutions also operate in every province and city/regency in Indonesia. 
A comprehensive and holistic standard of poverty needs to include spiritual aspect parallel with material aspect. So far, prevailing standards focus only on material part of poverty. For instance, the Central Board of Statistic (BPS) has a physical indicator approach in determining poverty line. The approach is based on food and non-food needs.

For example, in September 2014, the poverty line according to BPS is Rp $312,328.00 /$ capita/month. Individual whose income is equal to or less than this amount is considered as poor. The figure derived from food poverty line amounted $\mathrm{Rp} 229,469.00 /$ capita/month and non-food poverty line amounted $\mathrm{Rp}$ $82,859.00 /$ capita/month.

Based on the above conception, a research elaborating the effectiveness of zakat fund distribution by using not only material approach is highly needed. The research should also be based on spiritual perception. Therefore, Beik dan Arsyianti (2014) developed CIBEST model which can be referred for any research elaborating poverty alleviation. This paper aims to assess the productive zakat fund distribution program done by Dompet Dhuafa Amil Institution based on CIBEST model. Therefore, the research is objected to analyze mustahik households' income transformation before and after receiving zakat fund, and to analyze the poverty and welfare condition of mustahik household before and after productive zakat program based on CIBEST model.

\section{THEORETICAL FRAMEWORK OF CIBEST MODEL}

The CIBEST $^{2}$ model is a model developed by Beik dan Arsyianti (2014). The model is based on the holistic and comprehensive concept in examining poverty, which not only based on material aspect, but also spiritual facet. The concept is mainly based on Quran and hadith and also ijtihad of ulama (Islamic scholars) in defining basic needs of human, which according to Hafidhuddin (2013) comprises the needs to perform worship; the needs on food, clothes and housing; and the needs to security and safety feeling. In this context, two fundamental basic needs are material basic needs and spiritual basic needs (Quran Surah (QS) 20: 118-120 and QS 106: 3-4).

Furthermore, household in the CIBEST Model, is used as unit of analysis and divide the household into four possible situations with regard to their ability in fulfilling material and spiritual needs (Beik and Arsyianti, 2015). Firstly, a household that is able to fulfill both material and spiritual needs completely. This is called as prosperous household, which live under hayatan thayyibah (welfare) as mentioned by Allah SWT in the QS 16: 97.

Secondly, a household that is able to fulfill spiritual needs only, while they are unable to fulfill material needs up to the minimum level. This household lives

\footnotetext{
${ }^{2}$ CIBEST is an abbreviation of Center of Islamic Business and Economic Studies, a research center based at Institute of Research and Community Services (LPPM), Bogor Agricultural University, Indonesia. CIBEST in the name of the model is attached as the appreciation to the center that accommodates poverty alleviation researches done by Beik dan Arsyianti (2014).
} 
under material poverty. The QS 2: 155-156 state that Allah will test some people with lack of wealth, lack of fruits and other material needs. However, they have strong spiritual condition, which allows them to always surrender themselves to Allah and to maintain their patience and fortitude in the way of Allah (Beik and Arsyianti, 2015).

Thirdly, a household that is able to fulfill only material needs. They suffer spiritual deficiency. This household basically lives under spiritual poverty. Quranic verse, i.e. QS 6: 44, has described the presence of group of people who intentionally disobey Allah's rules. However, they are able to meet their material needs since they have excess of wealth and money.

Fourthly, a household that is not able to fulfill both material and spiritual needs. This household falls under absolute poverty as described by Allah in the QS 20: 124 . This is the weakest group in the society that should be given more attention in the development process of the country.

Based on this conception and typology of household, Beik and Arsyianti (2015) construct formula to compute welfare index, material poverty index, spiritual poverty index and absolute poverty index which are derived from CIBEST quadrant. This quadrant is based on the typology of household discussed above (vide Figure 1).

Based on the Figure 1, CIBEST quadrant is divided into four quadrants. A household that falls under the first quadrant is considered as materially and spiritually rich household. It is because the household can positively fulfill both material and spiritual needs. The second quadrant indicates the household that is materially poor and spiritually rich. The third quadrant portrays the materially rich and spiritually poor household, while the fourth one describes the materially and spiritually poor household (Beik and Arsyianti, 2015).

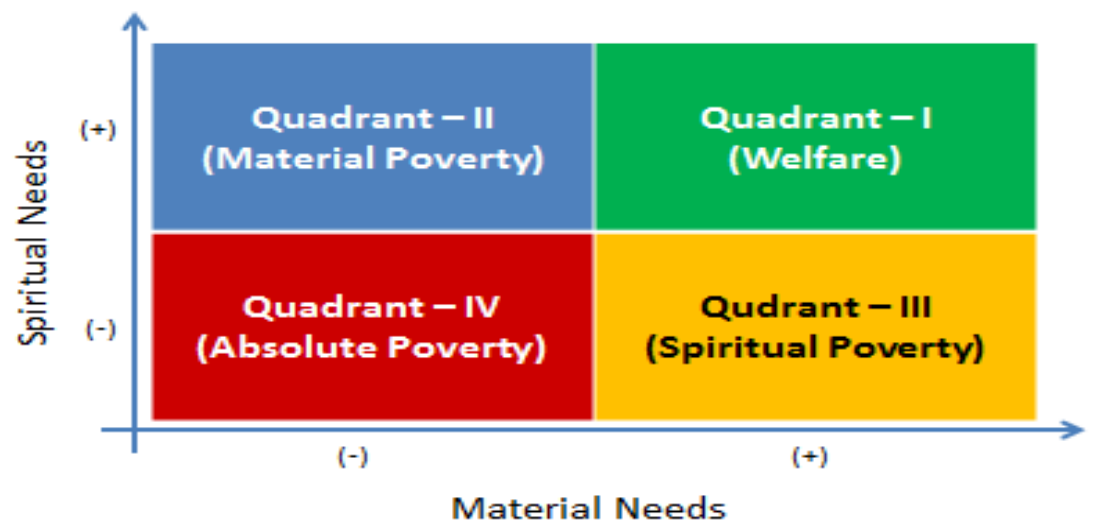

Figure 2: CIBEST Quadrant

Source: Beik dan Arsyianti 2014

Beik and Arsyianti (2015) argue further that spiritual needs should be based on three groups of variable comprising worship, household environment and government policy. Worship group consists of three variables, i.e. prayer, fasting and sharing (zakat and infaq), which are obligatory worship in the shariah 
perspective. Inability to fulfil these worships may reduce spiritual condition of the household and hence, may put them in the spiritual poverty.

The inclusion of household environment and government policy is because these two variables have strong influence towards commitment of household members to perform their worship (ibadah) as well as associated with a sense of security and freedom in performing the worship (Beik and Arsyianti, 2015). Specifically, Table 1 provides the details and indicators of these spiritual needs.

Table 1 Spiritual Needs Indicator

\begin{tabular}{|c|c|c|c|c|c|c|}
\hline \multirow{2}{*}{ Variables } & \multicolumn{5}{|c|}{ Likert Scale } & \multirow{2}{*}{$\begin{array}{c}\text { Poverty } \\
\text { Standard }\end{array}$} \\
\hline & 1 & 2 & 3 & 4 & 5 & \\
\hline Prayer & $\begin{array}{l}\text { Blocking } \\
\text { others to } \\
\text { pray }\end{array}$ & $\begin{array}{l}\text { Against the } \\
\text { concept of } \\
\text { prayer }\end{array}$ & $\begin{array}{l}\text { Performing } \\
\text { obligatory } \\
\text { prayer but } \\
\text { not on } \\
\text { regular } \\
\text { basis }\end{array}$ & $\begin{array}{l}\text { Always } \\
\text { performing } \\
\text { obligatory } \\
\text { prayer but not } \\
\text { in } \\
\text { congregational } \\
\text { prayer }\end{array}$ & $\begin{array}{l}\text { Performing } \\
\text { congregational } \\
\text { prayer for } \\
\text { obligatory one } \\
\text { and perform } \\
\text { recommended } \\
\text { prayer }\end{array}$ & \multirow{5}{*}{$\begin{array}{c}\text { Average } \\
\text { score for } \\
\text { spiritually } \\
\text { poor } \\
\text { household } \\
\text { is equal to } \\
3 \\
(\mathbf{S V}=\mathbf{3})\end{array}$} \\
\hline Fasting & $\begin{array}{l}\text { Blocking } \\
\text { others to } \\
\text { undertake } \\
\text { fasting }\end{array}$ & $\begin{array}{l}\text { Against the } \\
\text { concept of } \\
\text { fasting }\end{array}$ & $\begin{array}{l}\text { Not fully } \\
\text { performing } \\
\text { obligatory } \\
\text { fasting }\end{array}$ & $\begin{array}{l}\text { Performing } \\
\text { only } \\
\text { obligatory } \\
\text { fasting }\end{array}$ & $\begin{array}{l}\text { Performing } \\
\text { obligatory } \\
\text { fasting and } \\
\text { recommendable } \\
\text { fasting }\end{array}$ & \\
\hline $\begin{array}{l}\text { Zakat and } \\
\text { Infak }\end{array}$ & $\begin{array}{l}\text { Blocking } \\
\text { others to } \\
\text { pay zakat } \\
\text { and infak }\end{array}$ & $\begin{array}{l}\text { Against the } \\
\text { concept of } \\
\text { zakat and infak }\end{array}$ & $\begin{array}{l}\text { Not paying } \\
\text { infak at } \\
\text { least once } \\
\text { in a year }\end{array}$ & $\begin{array}{l}\text { Paying zakat } \\
\text { al-fitr and } \\
\text { zakat al-maal }\end{array}$ & $\begin{array}{l}\text { Paying zakat } \\
\text { al-fitr, zakat al- } \\
\text { maal, and infak }\end{array}$ & \\
\hline $\begin{array}{l}\text { Household } \\
\text { Environment }\end{array}$ & $\begin{array}{l}\text { Forbid } \\
\text { ibaadah }\end{array}$ & $\begin{array}{l}\text { Against } \\
\text { implementation } \\
\text { of ibaadah }\end{array}$ & $\begin{array}{l}\text { Consider } \\
\text { ibaadah as } \\
\text { private } \\
\text { matter for } \\
\text { household } \\
\text { member }\end{array}$ & $\begin{array}{l}\text { Support } \\
\text { execution of } \\
\text { ibaadah }\end{array}$ & $\begin{array}{l}\text { Creating } \\
\text { environment } \\
\text { which obligates } \\
\text { execution of } \\
\text { ibaadah }\end{array}$ & \\
\hline $\begin{array}{l}\text { Government } \\
\text { Policy } \\
\text { Environment }\end{array}$ & $\begin{array}{l}\text { Forbid } \\
\text { ibaadah }\end{array}$ & $\begin{array}{l}\text { Against } \\
\text { implementation } \\
\text { of ibaadah }\end{array}$ & $\begin{array}{l}\text { Consider } \\
\text { ibaadah as } \\
\text { private } \\
\text { matter }\end{array}$ & $\begin{array}{l}\text { Support } \\
\text { execution of } \\
\text { ibaadah }\end{array}$ & $\begin{array}{l}\text { Creating } \\
\text { environment } \\
\text { which obligates } \\
\text { execution of } \\
\text { ibaadah }\end{array}$ & \\
\hline
\end{tabular}

Source: Beik and Arsyianti (2015)

\section{RESEARCH METHODOLOGY \\ Source of Data}

Questionnaires were distributed on February and March 2015 in four rural areas and three districts in Bogor Regency. They are Babakan Village, Jampang Village, Jabon Village, and Kampung Anyar Village in Jampang, Ciseeng, and Parung districts. Those areas are targeted as the recipients of productive-based zakat program of Dompet Dhuafa, which is called Masyarakat Mandiri.

\section{Population and Sample}

Population of this program is as much as 200 households. By using simple random sampling method, 121 households have been selected as respondents of this research.

\section{Method of Data Analysis}


Application of CIBEST Model according to Beik and Arsyianti (2016) requires five stages of calculation. Those are:

1. Determination of material poverty line and spiritual poverty line.

Material poverty line (symbolized by MV) is derived from the following formula:

$$
M V=\sum_{i=1}^{n} P i M i
$$

whereby:

$\mathrm{MV}=$ minimum material needs standard (in terms of Rp or local currency)

$\mathrm{Pi}=$ price of goods and services $i$ (in terms of Rp or local currency)

$\mathrm{Mi}=$ minimum number of goods and services $i$ needed

This research in determining the value of MV uses BPS standard of poverty line and modifies the standard. Bogor regency poverty line used is $\mathrm{Rp}$ $300,119.00 /$ capita/month. Since CIBEST model requires household as unit of analysis, this per capita poverty line should be transformed into household poverty line. It is done by multiplying the poverty line with average household member in Bogor regency, respectively.

According to BPS (2014), the average household member in Bogor regency is equal to $\frac{322816}{81641}=3.954$ prior to the the program. It is derived from dividing total number of Bogor Regency population with total households in this area. After joining the program, average household member become $\frac{330475}{77331}=4.274$. By multiplying it with the poverty line, the MV values can be calculated as follow: $\mathrm{MV}_{1}=\operatorname{Rp} 259151 \times 3.954=$ Rp 1.024.706,00/household/month $\mathrm{MV}_{2}=\operatorname{Rp} 300119$ x $4.274=$ Rp 1.282.708,00/household/month whereby:

$\mathrm{MV}_{1}=$ modified Bogor regency poverty line before joining productive zakat program

$\mathrm{MV}_{2}=$ modified Bogor regency poverty line after joining productive zakat program

As for spiritual poverty line (symbolized by SV) it is equal to $3(\mathbf{S V}=\mathbf{3})$. It has also been portrayed in the Table 1 .

2. Calculation of spiritual score of the observed household prior to and after joining the productive-based zakat programs.

General formula to compute spiritual score of the observed household is as below:

$$
\mathrm{SS}=\sum_{k=1}^{n} \frac{S H k}{N}
$$

whereby:

SS = average score of actual spiritual condition of all observed households

$\mathrm{SH}=$ actual spiritual score of household $k$

$\mathrm{N}=$ total number of observed households

As for the value of $\mathrm{SH}$, it is obtained by applying the following formula: 


$$
\mathrm{SH}=\sum_{i=1}^{n} \frac{H 1+H 2+\cdots+H n}{M H}
$$

whereby:

$\mathrm{SH}=$ average score of actual spiritual condition of one household

$\mathrm{Hi}=$ actual spiritual score of household member $i$

$\mathrm{MH}=$ total number of household members

As for $\mathrm{Hi}$, its formula is as below:

$$
\mathrm{Hi}=\frac{V p i+V f i+V z i+V h i+V g i}{5}
$$

whereby:

$\mathrm{Hi}=$ actual spiritual score of household member $i$

$\mathrm{Vp}_{\mathrm{i}}=$ prayer score of household member $i$

$\mathrm{Vf}_{\mathrm{i}}=$ fasting score of household member $i$

$\mathrm{VZ}_{\mathrm{i}}=$ score of zakat and infak of household member $i$

$\mathrm{Vh}_{\mathrm{i}}=$ score of household environment based on perception of household member $i$

$\mathrm{Vg}_{\mathrm{i}}=$ score of government policy environment based on perception of household member $i$

3. Calculation of actual income or expenditure of the observed households.

This is important in order to determine whether their income or expenditure exceed the value of MV or not. Through this stage it will be known whether the household is materially rich or poor.

4. Grouped into CIBEST quadrant.

After having the values of MV, SV, actual score of spiritual and real income or expenditure of the observed households, then each household is grouped into the CIBEST quadrant by using the combination of their spiritual and material scores (vide Table 2).

Table 2 Combination of MV and SV Values

\begin{tabular}{ccc}
\hline Results & $\leq$ MV value & $>$ MV value \\
\hline$>$ SV value & Materially Poor and & Materially and Spiritually \\
& Spiritually Rich & Rich Household \\
& Household & (Quadrant I) \\
& (Quadrant II) & \\
\hline$\leq$ SV value & Materially and Spiritually & Materially Rich and \\
& Poor Household & Spiritually Poor Household \\
& (Quadrant IV) & (Quadrant III) \\
\hline
\end{tabular}

5. Calculation of each quadrant in order to obtain the values of welfare index, material poverty index, spiritual poverty index and absolute poverty index, respectively.

The formula of those indices is as below:

$$
W=\frac{w}{N}
$$

whereby:

$\mathrm{W}=$ welfare index $(0 \leq \mathrm{W} \leq 1)$

$\mathrm{W}=$ the number of spiritually and materially rich households 
$\mathrm{N}=$ the total number of observed households

$$
P m=\frac{M p}{N}
$$

whereby:

$\mathrm{Pm}=$ material poverty index $(0 \leq \mathrm{Pm} \leq 1)$

$\mathrm{Mp}=$ the number of materially poor and spiritually rich households

$\mathrm{N}=$ the total number of observed households

$$
P s=\frac{S p}{N}
$$

whereby:

Ps $=$ spiritual poverty index $0 \leq \mathrm{Ps} \leq 1$

$\mathrm{Sp}=$ the number of spiritually poor and materially rich households

$\mathrm{N}=$ the total number of observed households

$$
P a=\frac{A p}{N}
$$

whereby:

$\mathrm{Pa}=$ absolute poverty index $(0 \leq \mathrm{Pa} \leq 1)$

Ap $=$ the number of spiritually and materially poor households

$\mathrm{N} \quad=$ the total number of observed households

\section{RESULTS AND DISCUSSION}

\section{Zakat Impact on Income Improvement of Mustahik Household}

Data is tested using paired t-statistic test. The result shows significant $\mathrm{p}$-value of 0.000 . Since it is less than 5 percent, we reject H0. This indicates that the income level of mustahik household before and after joining productive zakat program is different at a confidence level of 95 percent.

The test also shows average income level before and after mustahik household joining the program. The average income level before joining the program is $\mathbf{R p}$ $\mathbf{8 7 4 , 0 0 0 . 0 0 / h o u s e h o l d / m o n t h ~ w h i c h ~ i s ~ b e l o w ~ t h e ~ p o v e r t y ~ l i n e . ~ A f t e r ~ j o i n i n g ~ t h e ~}$ program, the average income level becomes Rp 2,160,000.00/household/month, which is above the poverty line. Therefore, this program is statistically proved to have a significant impact on improving income level of mustahik household. The income level is increasing $\mathbf{1 4 7 . 1 4}$ percent.

\section{CIBEST Model Analysis}

To analyze the impact of productive-based zakat programs of Dompet Dhuafa, Table 3 below provides the spiritual score of the observed households.

Table 3 Average Spiritual Score of the Mustahik Households

\begin{tabular}{ccc}
\hline Variable & \multicolumn{2}{c}{ Average Spiritual Score } \\
\hline & $\begin{array}{c}\text { Pre-Zakat Program } \\
\left(\mathbf{S S}_{\mathbf{1}}\right)\end{array}$ & $\begin{array}{c}\text { Post-Zakat Program } \\
\left(\mathbf{S S}_{2}\right)\end{array}$ \\
\hline Shalat (Prayer) & 3.363 & 3.950 \\
\hline
\end{tabular}




\begin{tabular}{ccc}
\hline Fasting & 3.942 & 4.504 \\
Zakat and Infaq & 3.404 & 4.685 \\
Household Environment & 3.404 & 4.322 \\
$\begin{array}{l}\text { Government Policy } \\
\begin{array}{c}\text { Average Spiritual Score } \\
\text { of Total Observed } \\
\text { Households }\end{array}\end{array}$ & 3.826 & 4.702 \\
\hline \multicolumn{1}{c}{ Source: Primary Data (processed) } \\
\hline
\end{tabular}

Source: Primary Data (processed)

Furthermore, since the income or expenditure of the observed households is known, each household is grouped to CIBEST quadrant by combining with their spiritual score. The following Figure 3 portrays the results.

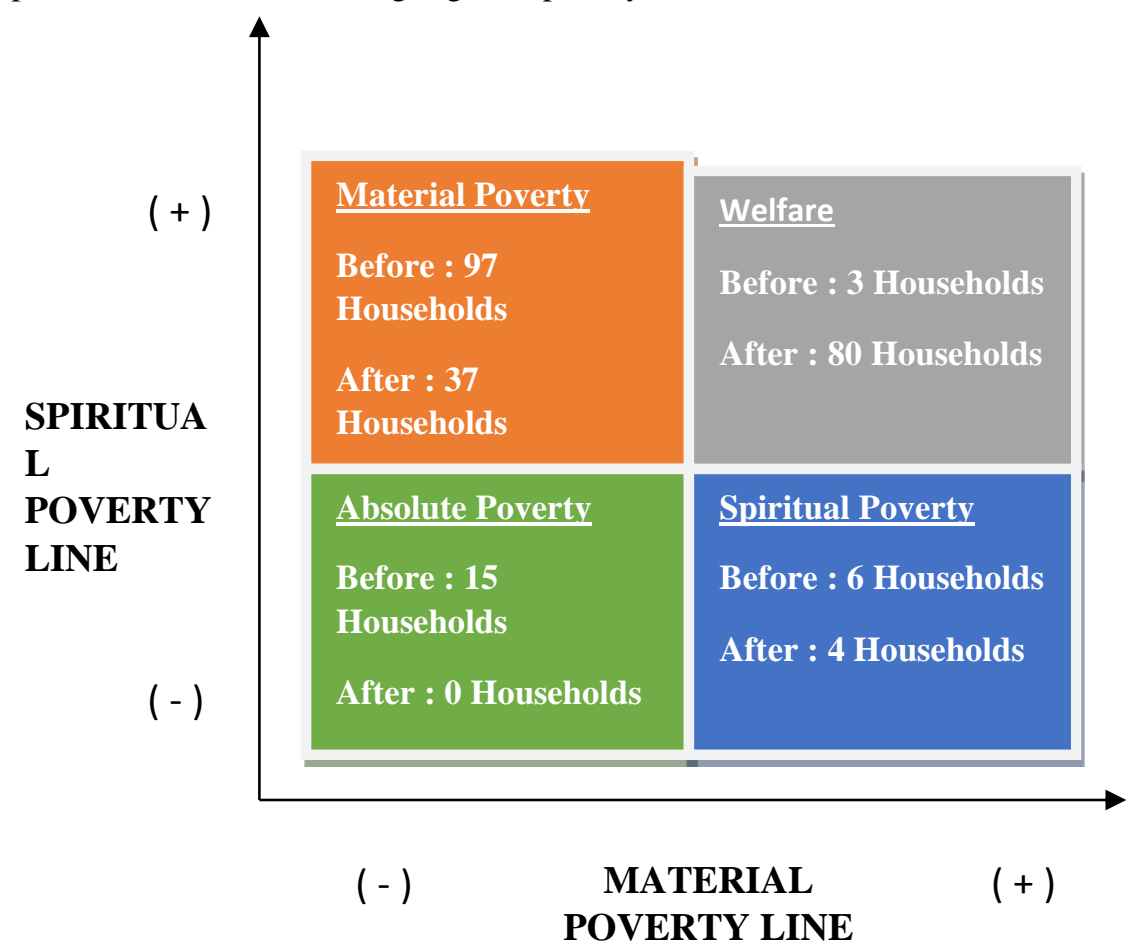

Figure 3 Grouping of Mustahik Based on CIBEST Quadrant (Pre and Post Zakat Program)

Source: Primary Data (processed) 
From the Table 3 it is found that basically the mustahik of Dompet Dhuafa spiritual score is good, i.e. 3.588, which is more than 3.00. Meanwhile, from Figure 3 , it is indicated that majority of the households is in the second quadrant ( 97 households) prior to productive-based zakat programs and only 3 households are in first quadrant. However, there are 6 households who are in the fourth quadrant and 15 in the third quadrant before joining the program.

After joining the program, mustahik household in the first quadrant become 80 households (increase 2566 percent). The spiritual score is also increasing. It becomes 4.433, which means that Dompet Dhuafa supervision in religious activities of the mustahik is successful.

Finally, the values of all indices can be calculated. The results can be found in the Table 4 below.

Table 4 CIBEST Index: Pre and Post Zakat Program

\begin{tabular}{cccc}
\hline CIBEST Index & $\begin{array}{c}\text { Pre Zakat } \\
\text { Program }\end{array}$ & $\begin{array}{c}\text { Post Zakat } \\
\text { Program }\end{array}$ & $\begin{array}{c}\text { Percentage } \\
\text { Change }\end{array}$ \\
\hline $\begin{array}{c}\text { Material Poverty } \\
\text { Index }\end{array}$ & 0,801 & 0,305 & 49,6 \\
$\begin{array}{c}\text { Spiritual Poverty } \\
\text { Index }\end{array}$ & 0,049 & 0,033 & 1,6 \\
$\begin{array}{c}\text { Absolute Poverty } \\
\text { Index }\end{array}$ & 0,123 & 0 & 12,3 \\
Welfare Index & 0,024 & 0,661 & 63,7 \\
\hline
\end{tabular}

From Table 4, the figure indicates that material poverty index is decreasing. The situation happened due to zakat fund distribution program and supervision offered in Masyarakat Mandiri Dompet Dhuafa. The mustahik feel that they are being helpful by this program, so they can improve their skill after joining Masyarakat Mandiri program.

The spiritual poverty index of mustahik is 0.049 before joining the program. After joining the program, the index is decreasing to 0.033 (1.6 percent). The result indicates that spiritual supervisory program done by Dompet Dhuafa is effective.

Before joining the program, absolute poverty index of the mustahik is 0.123 . After the program, the index becomes zero (0). The result indicates that none of the mustahik still in the absolute poverty condition after having the supervisory program given by Dompet Dhuafa.

Furthermore, welfare index of the mustahik is 0.024 before joining the program, and after participating in the program, the index is increasing to 0.661 or equal to 63.7 percent. The figure indicates that after being given supervision by Dompet Dhuafa, 63.7 percent of them have been able to fulfil material and spiritual needs. 


\section{CONCLUSION AND RECOMMENDATION}

According to the result, productive zakat fund program with supervision given by Dompet Dhuafa can improve mustahik households' income. The program also successfully brings the mustahik out of poverty. In average, mustahik households' income increases by 147.14 percent after participating in the program. Their income increases from Rp 874,000.00/month to Rp 2,160,000.00/month.

The program also successfully decreases material, spiritual, and absolute poverty indices by 49.6 percent, 1.6 percent, and 12.3 percent, respectively. Meanwhile, welfare index increases by 63.7 percent. Therefore, productive-based zakat fund distribution program can decrease material and spiritual poverty of the mustahik.

Therefore, in order to alleviate poverty, government and the society should integrate prevailing poverty alleviation programs. For Islamic social finance institutions, spiritual aspect of the mustahik must be taken into consideration in addition to material aspect.

\section{References}

Alimoeso, S. (2014). Pemanfaatan Data Keluarga Dalam Pembangunan Keluarga. Paper presented at BAZNAS National Seminar, Balikpapan.

Anriani. (2010). Analisis Dampak Zakat Terhadap Tingkat Kemiskinan Mustahik (Studi Kasus: Pendayagunaan Zakat oleh BAZ Kota Bogor di Tiga Kecamatan Kota Bogor). [undergraduate thesis]. Bogor (ID): Bogor Agricultural University.

Beik, IS. (2013). Economic Role of Zakat in Reducing Poverty and Income Inequality : A Case Study in the Province of DKI Jakarta, Indonesia. Germany: Lambert Academic Publishing.

Beik, IS., \& Arsyianti, LD. (2014). Measurement of Islamic Poverty and Welfare Indices: CIBEST Model. Paper presented in IRTI-IDB Workshop on Developing a Framework for Maqasid al Shariah based Index of SocioEconomic Development, Yogyakarta, 26-27 June.

Beik, IS., \& Arsyianti, LD. (2015). Construction of CIBEST Model as Measurement of Poverty and Welfare Indices from Islamic Perspective. AlIqtishad. 7(1).

Beik, IS., Arsyianti, LD. (2016). Ekonomi Pembangunan Syariah: Edisi Revisi. Jakarta (ID) : Rajagrafindo Persada.

[BPS] Badan Pusat Statistik. (2014). Jumlah dan Presentase Penduduk Miskin, Garis Kemiskinan, Indeks Kedalaman Kemiskinan $(P 1$, dan Indeks Keparahan Kemiskinan (P2), Menurut Provinsi Edisi September 2014. Badan Pusat Statistik, Jakarta.

[BPS] Badan Pusat Statistik Kabupaten Bogor. (2013). Penyusunan Perencanaan Target Indikator Ekonomi Daerah Kabupaten Bogor Tahun 2014-2018 (Laporan Akhir). Badan Pusat Statistik, Bogor Regency.

Purnamasari, N. (2010). Analisis Pengaruh Pendayagunaan Zakat, Infaq,dan Shadaqah terhadap Pengurang Kemiskinan (Studi Kasus: Pusat Zakat Umat LAZ Persis Garut).[undergraduate thesis]. Bogor (ID): Bogor Agricultural University.

Qardawi, Y. (2011). Hukum Zakat. Jakarta (ID) : Litera Antarnusa. 
Suprayitno, E. (2005). Ekonomi Islam: Pendekatan Ekonomi Makro Islam dan Konvensional. Yogyakarta (ID): Graha Ilmu.

Suyono, H. (2003). Memotong Rantai Kemiskinan. Jakarta (ID) : Yayasan Dana Sejahtera Mandiri.

Syahyuti. (2014). Mau ini Apa itu? "Komparasi Konsep, Teori, dan pendekatan dalam Pembangunan Pertanian dan Pedesaan: (125 versus125)”. Jakarta (ID) : Amplitudo Media Science.

Syarifuddin, A. (2005). Garis-Garis Besar Fiqih. Jakarta (ID): Kencana.

[TNP2K] Tim Nasional Percepatan Penanggulangan Kemiskinan. (2010). Pendahuluan Kebijakan [Internet]. Jakarta (ID); [retrieved on 26 December 2014]. Available at : http://www.tnp2k.go.id/id/kebijakanpercepatan/pendahuluan/.

[TNP2K] Tim Nasional Percepatan Penanggulangan Kemiskinan. 2010. Program Penanggulangan Kemiskinan di Indonesia [Internet]. Jakarta (ID); [retrieved on 26 December 2014]. Available at: http://www.tnp2k.go.id/id/program/sekilas/

Tsani, T. (2010). Analisis Dampak Distribusi Zakat Terhadap Tingkat Kemiskinan dan Kesenjangan Pendapatan (Studi Kasus Pendayagunaan Zakat oleh BAZDA Lampung Selatan. [undergraduate thesis]. Bogor (ID): Institut Pertanian Bogor.

Yogatama, RA. (2010). Variabel-Variabel yang Mempengaruhi Kepatuhan Menunaikan Zakat. [journal article manuscript]. Yogyakarta (ID). 